\title{
Principles, Practices and Disciplinary Power Struggles in Political Theory ${ }^{1}$
}

Eva Erman and Niklas Möller, The Practical Turn in Political Theory, Edinburgh University Press, 2018.

\section{Introduction}

The Practical Turn in Political Theory sounds like a monograph political theorists have been waiting for - a monograph that identifies "practices" as a uniting theme that runs through several recently influential debates on non-ideal theory, practice dependence, realism and pragmatist theories of legitimacy and democracy - and then discusses the promise and limits of this uniting theme for the future of political theory.

Its authors, Eva Erman and Niklas Möller, are amongst the most tenacious critics of recent criticisms of, and alternatives to, what they call "mainstream political theory" (passim) or "normativism" $(43,51)$. In The Practical Turn, they bring their previous criticisms together and present this combination as an inquiry into the role of social and political practices for political theorizing. In contrast to the surveyed debates, which, Erman and Möller allege, have been "overshadowed by 'ideologically' driven contestations about how to best pursue normative political theory" (7), they aim to "bring the field forward without an ideological superstructure" (7). Without specifying what they mean by "ideological", Erman and Möller propose to free contemporary political theory from such ideological drives by offering a "philosophically rigorous analysis" (7).

The Practical Turn is principally focused on showing how the claims to distinctiveness from "mainstream political theory" made in the surveyed debates either rest on flawed arguments or collapse into mainstream political theory. More precisely, it is focused on showing that the opposition between non-ideal theorists, practice-dependence theorists, realists and pragmatists and the mainstream is based on arguments that "do not hold" and, once the "flawed or too strong" conclusions drawn from these arguments are weakened, there is "no theoretically interesting opposition between the different camps" (18). If this book were to succeed in achieving this goal, the implications for these burgeoning debates in political theory would be serious.

Erman and Möller narrow their inquiry down to the question of "what role social and political practices should play in the justification of normative political principles" (9). The choice of this overarching research question, however, seems to be in tension with their aim of removing the 'ideological superstructure' of political theory, as well as the structure of their book. Firstly, this question assumes a particular understanding of political theory, based on a strong distinction between "is" and "ought", which has been a focal object of criticism in many of the debates covered in the book (see below). Even if Erman and Möller accurately surveyed the debates (which, I will seek to demonstrate below, they did not), they would have been an unlikely source for the answers Erman and Möller are looking for. Part of their point is to get away from concentrating on this question. They are meant to be "orthogonal to mainstream political theory" (Geuss 20008: 19). That "all five debates reach[ an impasse with regard to answering the overall research question of this book" (124) is then neither surprising nor particularly problematic. Secondly, a research question focused on theory building does not look well-matched with a book which devotes more

\footnotetext{
${ }^{1}$ I would like to thank Thomas Fossen, Enzo Rossi, Matt Sleat and, above all, Rob Jubb for their comments on earlier drafts of this manuscript. I am grateful to The Leverhulme Trust (ECF-2016-227) for supporting my research.
} 
than two thirds of its pages to the criticism of positions it deems either deeply flawed or uninteresting.

The tensions between the goals and principles Erman and Möller profess and their practice raise questions about what they might intend by using philosophically rigorous analysis to remove an ideological superstructure. First, there is the issue of whether rigorous analysis can be conducted on the basis of selective portrayals, omissions and misrepresentation. Given that difficulty, and the weakness of the positive proposals the The Practical Turn contains, the book is most plausibly read as driven by the very disciplinary power struggles it claims to aim to overcome (7). In that sense, The Practical Turn is not a good place to turn for understanding the debates it surveys or whether they manifest a "practical turn in political theory" or not; rather, it serves as a warning of how struggles over power can influence and even structure seemingly the most purely intentioned of practices.

\section{Misrepresentations, omissions, and selective portrayals}

In their opening sentence, Erman and Möller (1) claim that "[a]ll normative principles are both shaped in and applied to social and political practices". They are quick to point out that social and political practices are indeed important for the application of normative principles. They then claim that "[m] uch more contested is whether social and political practices also should play a role in the very justification of normative political principles" (1). The question of how normative principles are shaped in and by social and political practices is thus narrowed to the question of the role these practices should play for the justification of normative political principles.

However, Erman and Möller do not provide a motivation for this narrowing, which is repeated in the two assumptions that make up the "practice-based view" (15) which they claim to be shared by the heterogenous set of debates they survey. The first assumption is that "normative political principles are dependent on the practice which they are supposed to regulate, in the sense that the practice in different ways constrains or puts limitations on the principles" (15). The second shared assumption is that "thoroughgoing interpretation of the practice in question is required in order to theorise appropriate principles" (15). These assumptions supposedly justify focusing a book on the "practical turn in political theory" on arguments about why and how social and political practices should constrain normative principles. But is the interest of political theorists in practices primarily in the application of principles and/or the justification of principles? While Erman and Möller are right to point out that many of the proponents of the debates they survey do not reject normative principles per se (16), their perspective ignores two important issues. Firstly, the surveyed debates are internally divided on the very issue of the extent to which they share the two assumptions. While some positions within non-ideal theory or practice-dependence appear to share both these assumptions, many other proponents in realist, pragmatist and practice-dependence debates only share them to a very limited extent, if at all. Compare the accounts of non-ideal theory (Valentini 2012) with realism (Rossi and Sleat 2014; Sleat 2016). Many proponents of the debates might agree that political theorizing is dependent on the practices it seeks to address. Note the difference to the first shared assumption claimed by Erman and Möller. Political theorizing is a much wider term than normative political principles and may contain dimensions that cannot be expressed through normative principles. In addition, the reformulated assumption does not make political theory primarily about providing regulative principles and does not depend on looking at the differences between political theories as mainly about the kinds of constraints put on normative principles. Secondly, the very point of important contributions to these debates is to orient political theory away from the 
justification of normative principles or at least from being primarily concerned with justifying normative principles. Consider for example interpretive realism (Freeden 2012, 2014 and Horton 2017), Geuss' radical realism $(2008,2010)$ or Thomas Fossen's approach to legitimacy (Fossen 2013, 2019).

Two examples indicate the apparent disinterest Erman and Möller have in accurately characterizing the content of and positions of the participants in the debates they cover in The Practical Turn. Their misrepresentation of the (incorrectly quoted) line from Raymond Geuss' Philosophy and Real Politics that "ethics is usually dead politics" (Geuss 2008: 42) is typical of the shortfall of exegetic rigor. Erman and Möller take Geuss" remark to mean that when governed by ethics the "political domain [is] deprived of any real politics" (12). While this is a point that realists might make, it is not what Guess intended there. Geuss meant to historicize ethical theories by pointing out that they reflect past political struggles for power. As the full quote reveals: "Ethics is usually dead politics: the hand of the victor in some past conflict" (Geuss 2008: 42). Similarly, it is misleading to describe Chantal Mouffe as a pragmatist theorist, committed to "careful interpretive work examining the nature of the practice, such as its point and purpose according to the participants" (15). Mouffe is more usually described as a radical democrat, and has been criticized precisely for failing to show sufficient interest in the point and purpose of a practice to its participants and instead offering meta-theoretical exercises of ontological stipulation too remote from social practices to be useful to interpret the experiences of those involved, for instance of suffering (see McNay 2014).

The misrepresentations of realism in The Practical Turn are particularly astounding. One is that realists are mainly concerned with political legitimacy $(11-12,15$, chapter 6$)$. While legitimacy is indeed a focal concern of realist scholarship, it would be too quick to reduce realism to an interest in legitimacy. An important part of the point of realism is to seek to transform how we do political theory more broadly in a way which places emphasis on, for example, the sources of normativity, the shape of political judgment and how power relations influence the motivations of agents. Importantly, realism seeks to theorize not just for politics but also to theorize politics.

Erman and Möller connect the misrepresentation of realism as focused on legitimacy with another when they claim that realists "start out from the reality of 'dirty politics' and regard principles of legitimacy as distinctly political with little or no grounding in moral values" (12). They repeat it elsewhere (107-115) when they claim that realists require no normativity from outside politics. However, many of the realists discussed by Erman and Möller have explicitly discussed how they view the relationship between moral and political values. For a start, take the example of Bernard Williams, a principal inspiration not only for the moderate realists at the centre of Erman and Möller's portrayal of realism. Williams argues that realism entails the rejection of "the basic relation of morality to politics as being that represented" the moralism to which it is opposed. However, it "does not deny that there can be local applications of moral ideas in politics" (Williams 2005: 8; see also Hall 2015). Relatedly, Matt Sleat has argued that "[p]olitical values may have their origin outside of politics but for them to function as values for the political domain [...] it must be possible for us to view them as consistent with its constitutive features" (Sleat 2016: 252; see also Hall 2017: 297).

Realists do not deny the importance of morality for political normativity. What they are interested in is how these values are mediated to be used in politics, how they become political values, and what that may mean for their standing in politics. Their point is that private morality is mediated in certain ways when what is at issue are the relations between governments and their subjects. 
Insisting that realists do not see any space for morality in political normativity, despite being aware of these arguments, amounts to the willful misrepresentation of their views. Erman and Möller certainly should be aware of these lines of argument, since Robert Jubb and Enzo Rossi twice pointed them out to them in a pair of exchanges they quote in The Practical Turn (22-23, 67, 113, 143; see Jubb and Rossi 2015a-b; Erman and Möller 2015a; 2015d).

The allegation that realists use stipulations about the limits of the concept of politics, like Williams' distinction between politics and sheer domination, in order to quickly disqualify their opponents' political theories as non-political is another willful misrepresentation. Erman and Mölller would be right to claim that such a move "hardly constitutes an argument" (115). However, no realist makes such a move purely based on conceptual stipulation. For instance, for Williams (2005: chapter 1), there is a difference between the establishment of a political relationship and meeting the Basic Legitimation Demand. Whilst the former is driven by Williams' distinction between sheer domination and politics, the latter is a judgment made from within political disagreement and draws on a wide range of normative reasons, including moral ones that have been mediated politically: "political disagreement is not merely moral disagreement, and it need not necessarily involve it, though it may do so" (Williams 2005: 77).

The discussion of linguistic constraints on principles (chapter 3), in particular of Thomas Fossen's approach to legitimacy, further illustrates Erman and Möller's lack of grasp of the distinctive features of the views they dismiss. They claim that pragmatist political theorists misuse fully general Wittgensteinian or Brandomian ideas about language, including rule-following, family resemblance or score keeping, in order to derive specific normative conclusions. They are particularly concerned with normative conclusions that seek to rule out the kinds of universal principles typical of the liberal mainstream in political theory. In their most elaborated case, they argue that Thomas Fossen misuses pragmatist insights to establish metanormative and normative constraints on political principles. $^{2}$ As Fossen has stressed elsewhere though, his pragmatist approach does not seek "to justify an alternative set of norms, but to open up conceptual room for a different way of looking at a problem" (Fossen 2019: 296). He is not primarily concerned about constraining the possibility of universal principles as such, but with the lack of reflexivity in mainstream political theory about the relationship between theory and politics. Pragmatist projects like his do not fit the description of the "practical turn" Erman and Möller offer (61).

In a recent reply to Fossen, Erman and Möller (2017b) double down on their criticism presented in The Practical Turn, claiming that Fossen's pragmatist analysis of legitimacy adds nothing new to what all political theorists already know about legitimacy and that the pragmatist resources on which he draws are at best a source of inspiration. As Fossen "mistakes inspiration for argument" his account lacks "any form of normative content" (2017b: 84). This draws out a general concern with Erman and Möller's understanding of normativity in tension with many of the views driving the debates they survey. Erman and Möller (69) hold that

"we cannot extract every component of a normative principle from facts about the practice it is supposed to regulate, since in order for an account to be normative rather than merely descriptive, it must always in principle be possible for a person, group or

\footnotetext{
2 They make this claim whilst recognizing that Fossen is not engaged in the "usual", but rather in an "indirect" way "to put forward a genuine alternative in political theory" (44), because he "aims to supply a new perspective on [political legitimacy] which leads to a number of constraints on [...] a positive normative account of legitimacy" (45).
} 
community to be wrong about what should be done. Hence, not all sources of normativity utilised to theorise normative principles are entirely internal to the practice that the principles are intended to govern. Some are external in the sense that they are not necessarily extracted from the ideas, actions and beliefs of the participants."

Whether Erman and Möller are correct about normativity is not the issue (and cannot be resolved here). Instead, the issue is whether the understanding of normativity they use is compatible with the concerns motivating many of the debates they survey. Raymond Geuss' claim (2008: 16) that those committed to "[the] utterly fundamental division between Is and Ought, Fact and Value, or the Descriptive and the Normative in as rigorous and systematic a way as possible [...] have fallen prey to a kind of fetishism, attributing to a set of human conceptual inventions a significance they do not have" is arguably not only an important motivation for many realists, but also for Fossen's pragmatist approach to legitimacy. He contends that the division of labour standard in mainstream political theory "makes it seem as though 'normative theory' constitutes a self-standing domain of reflection, insulated from [...] other, supposedly non-normative lines of inquiry. Yet what we should consider substantially normative, as supposed to merely semantic or descriptive, is itself a normative question that should fall within the purview of (normative) political theory." (Fossen 2019: 301).

At times it seems as if Erman and Möller agree, as for example when they write that "what is normatively relevant is a first-order question, part of the normative argument, not a precondition for the theorist" (131). However, that agreement is only apparent. Later, they claim that "substantial argument, not semantics, should settle normative debates" (144), which clarifies that what is normatively relevant is only a matter of choice between the focus of normative principles, not semantic or descriptive aspects of politics. This is just one example of how Erman and Möller, who portray themselves as liberating normative political theory from undue constraints, effectively work as gatekeepers and boundary police, constraining the limits of what counts as political theory. They are either unable or unwilling to see that realists, some pragmatists, and some practice-dependence theorists are not primarily concerned with the authors' account of the "philosophical puzzles involved in elaborating the relationship between practice and principles" (151), but rather are engaged in a combination of philosophical and practical puzzles that defy a rigid is-ought distinction, centred around how we can provide orientation that is relevant and has critical edge for people like us. Once we view Fossen's project as not about the content or scope of normative principles, but in "explicat[ing] the ways in which the question of legitimacy manifests itself in practice, and the forms of activity through which we might engage it" (Fossen 2019: 303), we can recognize this project as an attempt to lift, rather than to impose, constraints on political theorizing.

The Practical Turn has then a number of faults which undermine its claim to philosophical rigor. Its misrepresentations of its interlocutors prevent it from providing a charitable reconstruction and reasonable assessment of some of the more original and radical departures from mainstream political theory it hopes to discuss. Instead, its research question and characterization of what is at stake in debates it covers suggest that Erman and Möller presuppose the criteria from the mainstream approach to political theory when engaging with authors who intend precisely to depart from that approach.

Positive contribution 
What then of the positive contribution Erman and Möller hope to make? Does it compensate for the problems with the pars destruens of The Practical Turn? Unsurprisingly, the main positive claim of the book is to argue that "the theorist has much more leeway in construing normative political principles than suggested in the five debates that are scrutinized" (5). In contrast to the constraints supposedly proposed by the surveyed debates, Erman and Möller suggest that "there is virtually no set of substantive methodological or justificatory constraints that the theorist attempting to justify a normative political principle in political theory needs to adhere to" (25). In the final chapter they still specify two (supposedly non-methodological and practice independent) sets of constraints on normative political principles which are supposed to replace the misunderstandings they identify at the heart of the practical turn in political theory (124-8): the first, the fitness constraint (131-142), falls into a negative component, which is about meeting a threshold of internal consistency, and a positive component. The latter is about the "justificatory force" (132) that a principle derives from other "premises and claims" of the political theory to which it belongs. The second, the functional constraint (142-150), is about any constraints due to what a "normative account aims to do, that is, what the suggested principle of the account is supposed to regulate and whether there are any particular limits within which it is intended to do so" (142).

Perhaps if one begins considering the various alternatives to mainstream political theory covered by The Practical Turn with an unquestioned commitment to the task of political theory being the production of normative principles, one might end up with this conclusion and its apparent concession to any realist or practice-dependent theorist interested in how moral claims might appropriately filter into politics. However, given that assumption and the misrepresentations outlined above, Erman and Möller's positive contribution does not and cannot speak to most of most of those alternatives. Had Erman and Möller interpreted the debates they surveyed more accurately and charitably, they might have found that many contributors to these debates are not primarily limited by abstract linguistic, epistemic, methodological, or political constraints, but rather, like Erman and Möller, by what they seek to achieve through their theorizing. They just differ from Erman and Möller about what it is appropriate to seek to achieve through political theory.

\section{Disciplinary Power Struggle and the State of the Debates in Political Theory}

While Erman and Moller provide some incisive arguments against some aspects of some of the debates they survey, these arguments do not add up to a general account of what might be wrong with the practical turn in political theory. It is not even clear whether they add up to provide the reader with a sufficiently developed account of what the practical turn may be, as the individual chapters do not bear out the initial claims about what unites the practical turn.

If a student who had previously not read any contributions to the debates surveyed in The Practical Turn judged them on the basis of this book alone, they would come away puzzled why these nonideal theorists, realists, practice-dependence theorists and pragmatists make so much ado about nothing. They might come away grateful that Erman and Möller finally apply 'philosophical rigor' to these debates that would otherwise have languished under the shadow of ideological superstructure'. Erman and Möller might genuinely have sought to rid political theory from ideology, but have instead produced a monograph that should be primarily remembered as an example of intra-disciplinary power struggles, here in defence of "normativism" or "mainstream political theory". First, it is otherwise difficult to make sense of the manifold misrepresentations. Second, the book offers few new insights that the authors have not previously published (Erman 
and Möller 2013, 2014, 2015a-d, 2016a-b, 2017a-b, 2018, 2019). Finally, why would the authors otherwise devote more than two thirds of its pages of a monograph aimed at explaining "what role social and political practices should play in the justification of normative political principles" (9) to criticizing the efforts of theorists whom the authors portray as either relying on flawed arguments or collapsing into mainstream political theory?

And yet The Practical Turn could be helpful reading for political theorists who want to challenge the mainstream while still trying to speak to it. The Practical Turn provides a flavour of the kind of lengths to which mainstream theorists might go to defend themselves, including uncharitable readings, leaving out key positions from the reconstructed debates, and arguing that the challenges to the mainstream should be discussed based on the view that the picture of political theorizing on which the mainstream relies is correct anyway. The book hence stands as a useful guide for at least two groups of people. Theorists who want to challenge the mainstream can study here the kind of attacks for which they should prepare. Others may instead infer a cautionary tale of the price involved in engaging in such disciplinary power struggles, both for those who wish to disturb paradigms and those who wish to defend them.

To sum up, The Practical Turn provides some insight into the state of, and stalemate in, contemporary political theory, including the acrimonious opposition between the mainstream and its critics. Despite its stated intentions, the book talks past its addressees and fails to show the standard of interpretive care and accuracy that would have been needed to lend credence to its challenges, some of which are interesting and compelling. The book hence fails to show that the debates it surveys are superfluous because they either rely on untenable arguments or are uninteresting, and so fall back on mainstream political theory. It is telling of the state of current debates that a book focused on practices in political theory hardly discusses any practices, but is rather nearly entirely methodological, meta-theoretical and general in outlook. This seems to be one of the reasons that productive dialogue has been so difficult between the mainstream and its critics. As Jubb (2019: 2) has suggested in the context of debates about realism, "attempting to adjudicate between realism and moralism at the level of precise and perfectly generalizable methodological prescriptions is in the end unsatisfactory because there is not sufficient common ground to agree on the prescriptions at stake, their meaning or their connections to each other". Part of the way forward for both sides might be to stop talking about first-order theorizing from a methodological and meta-theoretical point of view and instead engage in it. 


\section{References}

Erman, E and Möller, N (2013) Three failed charges against ideal theory. Social Theory and Practice 39(1): 19-44.

Erman, E and Möller, N (2014) 'Brandom and political philosophy. The Journal of Political Philosophy 22(4): 486-98.

Erman, E and Möller, N (2015a) Political legitimacy in the real normative world: the priority of morality and the autonomy of the political. British Journal of Political Science 45(1): 215-33.

Erman, E and Möller, N (2015b) What not to expect from the pragmatic turn in political theory: European Journal of Political Theory 14(2): 121-40.

Erman, E and Möller, N (2015c) Practices and principles: on the methodological turn in political theory. Philosophy Compass 10(8): 533-46.

Erman, E and Möller, N (2015d) Why political realists should not be afraid of moral value. Journal of Philosophical Research 40: 459-64.

Erman, E and Möller, N (2016a) What distinguishes the practice dependent approach to justice? Philosophy \& Social Criticism 42(1): 3-23.

Erman, E and Möller, N (2016b) Why democracy cannot be grounded in epistemic principles. Social Theory and Practice 42(3): 449-73.

Erman, E and Möller, N (2017a) Practice-dependence and epistemic uncertainty. Journal of Global Ethics 13(2): 187-205.

Erman, E and Möller, N (2017b) Political Legitimacy and the Unreliability of Language. Public Reason 8(1-2): 81-89.

Erman, E and Möller, N (2018) Political legitimacy for our world: where is political realism going? The Journal of Politics 80(2): 525-538.

Erman, E and Möller, N (2019) How practices do not matter. Critical Review of International Social and Political Philosopby 22(1): 103-118.

Fossen T (2013) Taking stances, contesting commitments: Political legitimacy and the pragmatic turn. Journal of Political Philosophy 21(4): 426-450.

Fossen, T (2019) Language and Legitimacy: Is Pragmatist Political Theory Fallacious? European Journal of Political Theory 18(2): 293-305.

Freeden, M (2012) Interpretive and Prescriptive realism. Journal of Political Ideologies 17(1): 1-11.

Freeden, M (2014): The 'Political Turn' in Political Theory. Journal of Political Ideologies 19(1): 1-14.

Geuss, R (2008) Philosophy and Real Politics. Princeton and Oxford: Princeton University Press.

Geuss, R (2010) Politics and the Imagination. Princeton and Oxford: Princeton University Press.

Hall, E (2015) Bernard Williams and the Basic Legitimation Demand: A Defence. Political Studies, 63(2), 466-480.

Hall, E (2017) How to do realistic political theory (and why you might want to). European Journal of Political Theory 16(3) 283-303.

Horton, J (2017) What might it mean for political theory to be more realistic? Philosophia 45(2): 487501.

Jubb, R (2019) On what distinctly political normativity is. Political Studies Review, https://doi.org/10.1177\%2F1478929919832251. 
Jubb, R and Enzo R (2015) Political norms and moral values. Journal of Philosophical Research 40: 4558 .

Jubb, R and Enzo R (2015) Why Moralists Should Be Afraid of Political Values: A Rejoinder. Journal of Philosophical Research 40: 465-8.

McNay, L (2014) The Misguided Search for the Political. Social Weightlessness in Radical Democratic Theory (Cambridge: Polity).

Rossi, E and Sleat, M (2014) Realism in Normative Political Theory. Philosophy Compass 9(10): 689-701.

Sleat, Matt (2016) Realism, Liberalism and Non-ideal Theory Or, Are there Two Ways to do Realistic Political Theory? Political Studies, 64(1), 27-41.

Valentini, L (2012) Ideal vs. Non-Ideal Theory: A Conceptual Map. Philosophy Compass 7(9): 654 64.

Williams, B (2005) In the Beginning was the Deed, ed. G Hawthorn (Princeton and Oxford: Princeton University Press). 